\title{
KAJIAN PELESTARIAN TRADISI MEGIBUNG DI DESA SERAYA TENGAH, KECAMATAN KARANGASEM, KABUPATEN KARANGASEM (PERSPEKTIF GEOGRAFI BUDAYA)
}

\author{
Putu Widiasih, I Gede Astra Wesnawa, I Gede Budiarta, \\ Jurusan Pendidikan Geografi \\ Universitas Pendidikan Ganesha \\ Singaraja, Indonesia \\ e-mail: putuwidiasih37@yahoo.com,gede astrawesnawa@yahoo.co.id, \\ budiartagdgeo@yahoo.co.id
}

\begin{abstract}
ABSTRAK
Penelitian ini bertujuan untuk mendeskripsikan: (1) landasan filosofis tradisi megibung di Desa Seraya Tengah Kecamatan Karangasem, (2) menganalisis nilai-nilai sosial budaya yang mendasari tradisi megibung di Desa Seraya Tengah Kecamatan Karangasem, dan (3) menganalisis pelestarian tradisi megibung di Desa Seraya Tengah Kecamatan Karangasen. Lokasi penelitian ini yaitu di Desa Seraya Tengah, Kecamatan Karangasem, Kabupaten Karangasem. Penelitian ini merupakan penelitian populasi dengan objek penelitian pelestarian tradisi megibung di Desa Seraya Tengah Kecamatan Karangasem, sedangkan subjek dalam penelitian ini adalah Bendesa Adat Pakraman Seraya, Kepala Desa yang ada di wilayah Desa Pakraman Seraya, Perangkat Desa Dinas, Perangkat Desa Adat, Tokoh Masyarakat. Data dikumpulkan dengan menggunakan metode wawancara, metode pencatatan dokumen, dan data dianalisis dengan menggunakan metode deskriptif kualitatif. Hasil penelitian ini menunjukkan bahwa: (1) tradisi magibung menjadi tradisi bagi masyarakat Karangasem, Khususunya masyarakat Desa Seraya Tengah yang masih tetap dipertahankan hingga saat ini yang lebih penting lagi bahwa megibung mengandung pendidikan moral bernilai tinggi seperti pendidikan etika, tata tertib, sopan santun, kesabaran, memupuk rasa kebersamaan dan kekeluargaan, saling menghargai. (2) di dalam tradisi megibung terdapat tiga nilai-nilai positif yang sangat menonjol, yaitu nilai kekeluargaan, nilai kebersamaan, nilai religius. (3) Sampai saat ini tradisi megibung masih tetap berlangsung dan tetap dipertahankan dari generasi ke generasi, hal tersebut terbukti sampai saat ini tradisi megibung masih tetap dilaksanakan oleh masyarakat Desa Seraya Tengah. Setiap dalam upacara keagamaan seperti upacara dewa yadnya, pitra yadnya, maupun manusia yadnya
\end{abstract}

Kata Kunci: Megibung dan tradisi adat 
The Research of Megibung Tradition Preservation at Seraya Tengah Village, Karangasem Distric, Karangasem regency ( cutural Geography perspective)

Putu Widiasih, I Gede Astra Wesnawa, I Gede Budiarta,

Student of Geography Education Departement

e-mail: putuwidiasih37@yahoo.com, gede astrawesnawa@yahoo.co.id, budiartagd geo@yahoo.co.id

\begin{abstract}
This study aims to describe: (1) the philosophical basis of the megibung tradition in Seraya Tengah Village, Karangasem Subdistrict, (2) to analyze the sociocultural values underlying the megibung tradition in Seraya Tengah Village, Karangasem Subdistrict, and (3) to analyze the preservation of the megibung tradition in the village Seraya Tengah Kecamatan Karangasen. The location of this research is in Seraya Tengah Village, Karangasem District, Karangasem Regency. This research is research of population with object of research of preservation of megibung tradition in Seraya Tengah Village Karangasem Subdistrict, while subject in this research is Bendesa Adat Pakraman Seraya, Village Head in Desa Pakraman Seraya Village, Village Device of Dinas, Device of Indigenous Village, Data were analyzed using interview method, document recording method, and data analysis technique using qualitative descriptive method. The results of this study indicate that: (1) the magibung tradition became a tradition for the people of Karangasem, especially the people of Seraya Tengah Village which are still maintained until today more importantly that megibung contains high moral education such as ethics education, Patience, cultivate a sense of togetherness and kinship, mutual respect. (2) in the megibung tradition there are three very prominent positive values, namely the values of kinship, the value of togetherness, the religious value. (3) Until now the tradition of megibung is still ongoing and still maintained from generation to generation, it is proven until now the tradition of megibung still implemented by the people of Seraya Tengah Village. Each in a religious ceremony such as the ceremony of the god yadnya, pitra yadnya, and human yadnya
\end{abstract}

Keywords: Megibung and Indigenous Traditions

\title{
PENDAHULUAN
}

Geografi merupakan suatu disiplin ilmu yang mempelajari pada interaksi manusia dengan lingkungan tempat tinggal manusia sebagai suatu hunian. Geografi mempelajari hubungan kausal gejala-gejala di permukaan bumi dan peristiwa-peristiwa yang terjadi di permukaan bumi, baik secara fisik maupun yang menyangkut makhluk hidup beserta permasalahannya melalui pendekatan keruangan, ekologi, dan regional untuk kepentingan program, proses, dan keberhasilan pembangunan. Geografi juga memiliki cabang ilmu untuk mengkaji aspek kebudayaan pada suatu daerah, yaitu Geografi Budaya. Geografi Budaya merupakan ilmu pengetahuan yang menelaah sekitar tingkah laku manusia yang ditimbulkan karena adanya usaha adaptasi dan pemanfaatan lingkungan alam oleh manusia dalam usaha mempertahankan hidupnya (Sauer, 1982 dalam Sudiantika, 2014). Hal tersebut memiliki arti bahwa Geografi Budaya merupakan 
penengah bagi kajian yang bersifat fisik dengan kajian yang bersifat sosial. Geografi Budaya juga merupakan rumpun Geografi yang lebih dekat dikaitkan dengan kajian Geografi Manusia (Human Geografi) (Sudiantika, 2014).

Tradisi dalam suatu masyarakat senantiasa mengalami perubahan yang semua itu merupakan bagian dari kebudayaan. Dari pemahaman tersebut maka apapun yang dilakukan oleh manusia secara turun temurun dari setiap aspek kehidupannya yang merupakan upaya untuk meringankan hidup manusia dapat dikatakan sebagai tradisi yang berarti bahwa hal tersebut adalah menjadi bagian dari suatu kebudayaan. Secara khusus tradisi adalah suatu proses pewarisan atau penerusan norma-norma, adat istiadat, kaidah-kaidah, dan berupa hartaharta. (Setyadi, 2014)

Provinsi Bali yang terletak di tengah-tengah wilayah Negara Republik Indonesia didiami oleh masyarakat religius, yang melahirkan seni budaya unik dalam kehidupan sehari-hari yang terkenal di seluruh dunia. Masyarakat Bali merupakan suatu kelompok manusia yang terkait oleh kesadaran akan kesatuan kebudayaannya. Walaupun ada kesadaran yang demikian, namun kebudayaan Bali mewujudkan banyak variasi dan perbedaan. (Sudaryathi, 2014)

Kebudayaan Bali merupakan salah satu bagian dari kebudayaan Indonesia yang sudah dikenal keunikannya hampir diseluruh belahan dunia. Keunikan tersebut dikarenakan oleh kebudayaan Bali tersebut didasarkan atas kepercayaan keagamaan yang kuat, yaitu kepercayaan agama hindu. Jiwa kebudayaan Bali dapat dikatakan berdasar pada agama Hindu dan lembaga adat istiadat sebagai wadahnya. Tanpa agama Hindu kebudayaan Bali mungkin tidak akan berkembang dan akan mati, sebaliknya ajaran agama Hindu juga tidak akan berkembang tanpa adanya suatu dukungan melalui kebudayaan Bali (Basudewa, 2014:12)

Bali merupakan salah satu wilayah Republik Indonesia yang juga memiliki kekayaan budaya, Adat Istiadat yang beraneka ragam. Kebudayaan Bali merupakan perpaduan yang utuh antara tradisi Bali dengan agama dan kebudayaan Hindu dimana ketiga aspek tersebut saling mempengaruhi satu sama lain. Inilah yang menjadi dasar pembentukan identitas manusia dan masyarakat manusia. Oleh karena itu, dasar - dasar jati diri etnik Bali dibentuk berlandaskan atas perpaduan antara kebudayaan Bali asli dengan kebudayaan Hindu ( Permana, 2013).

Diantara Kabupaten-Kabupaten yang ada di Bali, salah satunya Kabupaten yang dikenal banyak memiliki tradisi dan kebudayaan yang unik yakni Kabupaten Karangasem dengan ibu kotanya Amlapura. Kabupaten Karangasem juga dikenal memiliki berbagai macam tradisi dan kebudayaan yang beraneka ragam, keberagaman tradisi dan budaya tersebut tersebar di 8 kecamatan yang ada di Kabupaten Karangasem.

Kewajiban bagi keluarga yang mengadakan upacara yadnya haruslah menyediakan hidangan bagi orang-orang yang menyertai upacara yadnya tersebut, baik itu kerabatnya sendiri ataupun para undangan. Terkait dengan penyuguhan hidangan dalam upacara yadnya, masyarakat di Kabupaten Karangasem memiliki tradisi yang unik dan menarik dalam hal penyuguhan hidangan kepada para tamu dalam upacara yadnya. Kabupaten Karangasem yang dikenal kaya dengan adat dan tradisi memiliki sebuah tradisi yang sangat unik dan khas dalam hal menyuguhkan hidangan kepada para tamu dan kerabat dalam kegiatan upacara dan upakara yadnya, yang dikenal dengan istilah "Megibung" (Bahasa Bali).

Megibung merupakan suatu proses atau kegiatan yang dilakukan oleh masyarakat atau sebagian orang untuk duduk bersama saling berbagi satu sama lain, terutama dalam hal makanan. Tidak hanya perut wareg (kenyang) yang 
didapat dari kegiatan ini namun sembari makan kita dapat bertukar pikiran bahkan bersendagurau satu sama lain. Dalam pelaksanaan Megibungsemua orang melakukan kegiatan makan bersama dimana semua orang berbaur menjadi satu. Tidak ada perbedaan antara orang yang satu dengan orang yang lain, baik itu orang kaya atau miskin. seperti tradisi dan budaya Megibung yang ada di Kabupaten Karangasem tepatnya di Desa Seraya Tengah melakukan suatu tradisi Megibung ketika prosesi berlangsungnya Upacara Adat dan Keagamaan di Desa Seraya tengah. Seperti misalnya dalam Upacara Dewa Yadnya, Pitra Yadnya, Bhuta Yadnya, Rsi Yadnya dan Manusa Yadnya atau yang dikenal dengan nama Panca Yadnya (Bayu permana, 2013)

Dalam upacara Panca Yadnya tradisi Megibung (Bahasa Bali) ini dilakukan setelah melalui kegiatan yang istilah Bali dinamakan "Mebaf" (Bahasa Bali). Mebat ini merupakan prosesi mengolah bahan-bahan makanan dari mentah menjadi siap untuk dimakan yang nantinya digunakan sebagai hidangan untuk prosesi Megibung itu sendiri. Setelah prosesi Mebat ini selesai barulah kegiatan Megibung itu berlangsung. Dalam pelaksanaan Megibung ini dipandu dengan mulai dari cuci tangan, duduk, makan, berdiri, dan sampai cuci kembali. Semua memiliki aturan atau tata krama. Aturan-aturan tersebut tidak tertulis, namun aturan tersebut bersumber dari kebiasaan yang merupakan tradisi sehingga wajib dilakukan secara turun-temurun. Apabila aturan-aturan tersebut dilanggar, memang tidak ada sanksinya akan tetapi berdampak pada orang yang melanggarnya. Karena hal tersebut menyangkut harga diri sesorang. Orang yang melanggar aturan tersebut akan dikatakan tidak disiplin dan tidak punya etika atau tata krama.

Terdapat berbagai macam nilai-nilai luhur dalam proses Megibung, yaitu nilai sosial, hal tersebut dapat dilihat dari adanya rasa kebersamaan dan gotong royong dalam mempersiapkan bahan makanan (gibungan) (Bahasa Bali). Selain nilai sosial, dalam megibung juga terdapat nilai kebudayaan hal ini dapat di buktikan bahwa tradisi megibung merupakan sebuah warisan yang diwariskan oleh para leluhur yang masih tetap dipertahankan sampai saat ini.Magibung berasal dari kata Magi dan Buwung. Magi berarti kegiatan membagi-bagikan, sedangkan Buwung berarti batal. Jadi megibung berarti batal membagi, yang dimaksud yakni batal membagi-bagikan nasi karena kurangnya tempat, sehingga dapat dilakukan dengan makan bersama.

Terciptanya tradisi megibung seperti yang masih tetap dilaksanakan di Desa Pakraman Seraya Tengahsampai saat ini, merupakan suatu kebanggaan masyarakat di Karangasem, khususnya masyarakat Desa Pakraman Seraya Tengah. Karenaselain tradisi megibung tersebut merupakan sebuah warisan dari para leluhur mereka, dalam proses megibung mengandung tata nilai dan persaudaraan yang sangat kuat yang dapat menyatukan masyarakat tanpa harus membeda-bedakan derajat dan status sosial yang sering menjadi jurang pemisah dan penyebab konflik di tengah masyarakat. Setiap pertemuan maupun acara adat di Desa Pakraman Seraya Tengah, tradisi megibung ini tidak pernah absen untuk dilaksanakan.

Tradisi megibung paling sering dilaksanakan saat pelaksanaan upacara yadnya maupun dalam pertemuan keluarga. Setiap prosesi upacara keagamaan senantiasa disertai dengan kegiatan makan bersama atau megibung. Akan tetapi, di Era Globalisasi saat ini terlebih dengan adanya kemajuan ilmu pengetahuan dan teknologi, tradisi megibung mulai terancam keberadaanya dan ditinggalkan oleh sebagian masyarakat di Kabupaten Karangasem. Memudarnya tradisi ini disebabkan karena adanya anggapan dimasyarakat bahwa makan bersama (megibung) merupakan pemborosan, karena untuk melaksanakan perlu lebih banyak biaya. Selain itu, ada anggapan bahwa megibung dapat 
menularkan penyakit dari orang yang diajak megibung, sehinggaketika melaksanakan upacara keagamaan atau pertemuan masyarakat lebih memilih menghidangkan makanan dengan cara Prasmanan agar lebih praktis dan terlihat modern. Namun, disisi lain tradisi megibung perlu dikembangkan dan dilestarikan karena di dalamnya terkandung nilai-nilai sosial budaya sangat kental.

Melihat keadaan tersebut, peneliti ingin mengkaji lebih mendalam mengenai tradisi megibung di Desa Seraya Tengah Kecamatan Karangasem Kabupaten Karangasem. Berdasarkan hal tersebut, maka akan muncul beberapa permasalahan yang layak untuk dikedepankan, yaitu : (1) Apa yang menjadi landasan filosofis tradisi megibung di Desa Seraya Tengah? (2) Nilai - nilai sosial budaya apa saja yang mendasari tradisi megibung di Desa Seraya Tengah? (3) Bagaimana pelestarian tradisi megibung di Desa Seraya Tengah?

Daerah ini dijadikan sebagai objek penelitian, mengingat dearah tersebut merupakan Desa Tua (Baliaga) yang dikenal sebagai tempat tumbuhnya tradisi megibung. Selain itu, tradisi megibung didesa ini memeiliki sejarah yang sangat lama serta memiliki ciri khas tersendiri seperti jumlah satu seka(Bahasa Bali) megibung yang berjumlah delapan orang. Berbagai macam aturan unik yang harus ditaati dan lain sebagainya.

Tujuan dari penelitian (1) Mendeskripsikan landasan filosofis tradisi megibung di Desa Seraya Tengah Kecamatan Karangasem Kabupaten Karangasem. (2) Menganalisis nilai - nilai sosial budaya yang mendasari tradisi megibung di Desa Seraya Tengah Kecamatan Karangasem Kabupaten Karangasem. (3) Menganalisis pelestarian tradisi megibung di Desa Seraya Tengah Kecamatan Karangasem Kabupaten Karangasem.

\section{METODE}

Penelitian ini dilakukan di Desa Seraya Tengah Kecamatan Karangasem Kabupaten Karangasem. Objek dalam penelitian ini pelestarian tradisi megibung. Memperhatikan Objek Penelitian tersebut, yang menjadi subjek dalam penelitian ini adalah Bendesa Adat Pakraman Seraya, Kepala Desa yang ada di wilayah Desa Pakraman Seraya, Perangkat Desa Dinas, Perangkat Desa Adat, Tokoh Masyarakat. Penelitian ini menggunakan rancangan penelitian deskriptif. Data yang digunakan adalah data primer dan sekunder. Data sekunder bersumber dari wawancara yang dilakukan Bendesa Adat Pakraman Seraya, Kepala Desa yang ada di wilayah Desa Pakraman Seraya, perangkat Desa Dinas, perangkat Desa Adat, tokoh masyarakat, serta seluruh masyarakat di Desa Pakraman Seraya Tengah, Kecamatan Karangasem. Data primer yang telah dikumpulkan selanjutnya akan dianalisis menggunakan analisis deskriptif kualitatif.

\section{HASIL DAN PEMBAHASAN}

\section{Landasan Filosofis Tradisi Megibung di Desa Seraya Tengah Kecamatan Karangasem Kabupaten Karangasem}

Berdasarkan hasil penelitian yang telah dipaparkan sebelumnya, bahwa tradisi megibung sudah ada sejak dahulu kala. Awal mula lahirnya tradisi megibung yang hingga saat ini masih tetap dipertahankan, dimulai saat I Gusti Anglurah Ketut Karangasem menjadi Senapati di Kerajaan Karangasem sekitar tahun 1614 Caka atau 1692 Masehi. Tradisi megibung ini diawali ketika terjadi perang antar kerajaan nusantara, yang bertujuan untuk memperluas daerah kekuasaan. Dalam pertempuran tersebut, banyak menguras energi dari para prajurit Kerajaan Karangasem, sehingga para prajurit tersebut menjadi sangat lapar. Pada saat para sipir (petugas membawa makanan kerajaan) yang akan 
diberikan kepada para prajurit, peralatan yang akan digunakan untuk membagi makanan tidak mencukupi karena banyaknya prajurit yang akan diberi makan. Sedangkan saat itu, belum ada perabotan yang lengkap seperti sekarang yang ada hanya wadah dari kau kulak (tempurung kelapa). Dalam situasi seperti itu, akhirnya I Gusti Anglurah Ketut Karangasem selaku senapati memerintahkan kepada petugas yang membawa makanan untuk membatalkan membagi-bagikan makanan dan memerintahkan kepada prajuritnya untuk memakan makanan tersebut secara bersama-sama menggunakan peralatan perang yang ada berupa tameng (ende) yang dibawa oleh prajurit tersebut sebagai alat berperang.

Sejak saat itulah dikenal istilah megibung. Megibung berasal dari kata magi dan buung, magi berarti membagi dan buung berarti batal. Sehingga megibung berarti batal membagi-bagi makanan secara terpisah dan memakan makanan secara bersama-sama. Selain karena kekurangan tempat makan, megibung berfungsi menghitung jumlah prajurit. Oleh karena itu Sang Senapati memerintahkan kepada prajuritnya untuk membentuk kelompok. Satu kelompok terdiri dari delapan orang yang disebut dengan istilah satu sela. Sejak saat itulah magibung menjadi tradisi bagi masyarakat Karangasem, Khususunya masyarakat Desa Seraya Tengah yang masih tetap dipertahankan hingga saat ini yang lebih penting lagi bahwa megibung mengandung pendidikan moral bernilai tinggi seperti pendidikan etika, tata tertib, sopan santun, kesabaran, memupuk rasa kebersamaan dan kekeluargaan, saling menghargai.

Makna yang terkandung di dalam tradisi megibung adalah menjaga persatuan dan kesatuan. Megibung penuh dengan nilai-nilai kebersamaan, nilai kekeluargaan dan nilai religius. Orang-orang yang megibung harus mengikuti tata tertib dan aturan makan yang ketat, I Ketut Widya mengatakan saat megibung tidak boleh bicara dan ketawa keras, berteriak-teriak, bersendawa, bersin, berdahak, meludah, dan kentut. Ketika selesai makan, orang tidak boleh sembarangan meninggalkan tempat harus menunggu orang atau sela lain menyelesaikan makannya. Ketika semua orang atau sela telah menyelesaikan makannya, maka para megibung mempersilahkan orang-orang meninggalkan tempat. Makan bersama ini harus diakhiri secara bersama-sama juga. Aturan megibung di setiap tempat di Karangasem biasanya berbeda-beda sesuai desa (wilayah), kala (waktu), patra (kondisi) setempat.

Hasil penelitian ini sesuai dengan temuan dari Permana (2013) dalam skripsi yang berjudul "Megibung Dalam Pemertahanan Tradisi Adat dan Budaya di Desa Adat Kemoning Kecamatan Klungkung Kabupaten Klungkung Dilihat dari Dimensi Nilai Moral Pancasila Tahun 2013" mengemukakan bahwa filosofis dari tradisi megibung adalah menanamkan pola kebersamaan, gotong royong, persatuan, keadilan demokrasi, kemanusiaan dan juga ketuhanan dalam kehidupan bermasyarakat sehingga orang merasakan rasa kebersamaan dalam persaudaraan diterapkan dalam kehidupan sehari-hari.

\section{Nilai - Nilai Sosial Budaya yang Mendasari Tradisi Megibung di Desa Seraya Tengah Kecamatan Karangasem Kabupaten Karangasem}

Sebagai suatu tradisi yang tumbuh dan hidup di dalam masyarakat, tentu memiliki nilai-nilai positif yang terkandung di dalam tradisi tersebut, sehingga mampu dipertahankan oleh masyarakat. Sama halnya dengan tradisi megibung yang masih tetap bertahan sampai saat ini mengandung nilai-nilai positif yang terkandung didalamnya. Secara umum terdapat empat nilai positif, keempat nilai tersebut yaitu nilai kekeluargaan, nilai kebersamaan, nilai religius, dan nilai toleransi. Namun dilihat dari tabel 4.14 dari keempat nilai tersebut, nilai yang paling menonjol ialah nilai kebersamaan dan nilai kekeluargaan. Hal tersebut 
dilihat dari proses pengerjaannya yang selalu dilakukan secara musyawarah dan semangat kebersamaannya terlihat dalam pelaksanaan megibung.

\section{Nilai kekeluargaan}

Pelaksanaan megibung telah memupuk nilai kekeluargaan di dalam kehidupan masyarakat Desa Seraya Tengah. Hal tersebut terlihat dari proses megibung yang pengerjaannya selalu dilakukan secara musyawarah. Semua proses pembuatan gibungan mulai dari persiapan sampai selesai megibung dilakukan untuk masyarakat Desa Seraya Tengah. Dalam megibung orang tidak memandang status sosial, tidak membedakan kaya atau miskin, ganteng atau cantik, berkasta atau tidak. Semua orang duduk menjadi satu dan makan makanan yang sama dalam satu wadah. Dengan cara seperti itu akan menghindarkan seseorang dari rasa ego yang dapat menjadi jurang pemisah di masyarakat karena adanya perbedaan status sosial dan mempererat rasa kesatuan di dalam masyarakat.

\section{Nilai kebersamaan}

Semangat gotong royong sangat kental terlihat dalam pelaksanaan megibung, nilai kebersamaan tersebut terpancar sejak mulai dari persiapan bahan dan alat sampai pada proses selesai megibung. Ketika pelaksanaan upacara yadnya masyarakat Desa Seraya Tengah bahu membahu serta bekerjasama guna menyiapkan bahan dan alat yang akan digunakan untuk membuat gibungan. Semangat kerja keras dari masyarakat Desa Seraya Tengah tersebut dilaksanakan secara tulus dan tanpa mengharapkan imbalan. Setelah semua persiapan selesai, maka gibungan akan disebar mencari tempat yang luas dan tuan rumah akan mempersilahkan undangan untuk megibung, kemudian para undangan akan saling mengingatkan untuk makan dan masing-masing undangan akan membagi diri membentuk kelompok menjadi delapan orang dan secara bergilir untuk melaksanakan megibung. Sementara undangan yang belum dapat giliran makan secara sukarela akan melayani semua permintaan yang diperlukan oleh undangan yang sudah dapat giliran makan seperti air minum, sayur, dan yang lainnya. Begitu juga sebaliknya, undangan yang sudah selesai makan akan melayani undangan yang belum mendapat giliran makan.

\section{Nilai religius}

Nilai lain yang juga terkandung di dalam tradisi megibung adalah nilai-nilai religius. Nilai-nilai religius ini sangat kental terlihat dalam setiap tahapan maupun proses pelaksanaan megibung. Hal tersebut dikarenakan, secara tidak langsung tradisi megibung sangat berkaitan dengan upacara yadnya baik upacara manusia yadnya, pitra yadnya, maupun dewa yadnya. Dikatakan demikian karena kegiatan megibung biasanya dilaksanakan saat ada upacara yadnya.

Megibung tidak hanya sekedar makan bersama, dalam megibung terdapat banyak makna yang terkandung dalam tradisi tersebut, oleh karena itu dalam setiap tahapan pembuatan gibungan selalu berpedoman pada ajaran agama hindu. Nilai-nilai religius tersebut terkandung dalam proses megibung, yaitu ngejot. Ngejot adalah proses sebelum pelaksanaan megibung yakni dengan menghaturkan gibungan kepada para leluhur, para dewa, dan bhuta kala, sebagai wujud syukur kepada tuhan yang maha esa, ida sanghyang widhi wasa, karena telah diberikan rejeki yang melimpah. Sebelum megibuung dilaksanakan, tuan rumah yang memiliki acara akan terlebih dahulu ngejot kepada para dewaa dan leluhur serta bhuta kala agar mendapatkan pahala atau surga syuta. 
Nilai Toleransi

Toleransi dalam tradisi megibung ialah saling menghargai antar sesama dan tidak membeda-bedakan status sosial yang ada dalam masyarakat tersebut dan saling menjaga perasaan atau saling menghormati. Dengan adanya nilai toleransi maka tradisi megibung dapat dilaksanakan dengan baik.

Tradisi megibung mengandung nilai-nilai positif yang sangat besar, nilainilai tersebut merupakan cerminan dari budaya luhur dari para nenek moyang yang harus dijadikan panutan oleh para generasi muda agar tidak terlena dalam rayuan dan godaan budaya luar yang banyak bertentangan dengan budaya yang diwariskan oleh para leluhur. Kesemua nilai tersebut sangat besar manfaatnya dalam menjaga persaudaraan dan kekeluargaan dalam masayarakat.

Hasil penelitian ini sesuai dengan temuan dari Permana (2013) dalam skripsi yang berjudul "Megibung Dalam Pemertahanan Tradisi Adat dan Budaya di Desa Adat Kemoning Kecamatan Klungkung Kabupaten Klungkung Dilihat dari Dimensi Nilai Moral Pancasila Tahun 2013" mengemukakan bahwa tradisi megibung banyak mengandung nilai-nilai, termasuk nilai-nilai moral pancasila. Berbicara tentang nilai-nilai moral pancasila semua nilai-nilai moral pancasila tersebut dilaksanakan di dalam tradisi megibung. itu artinya kalau ditinjau dari nilai-nilai moral pancasila, tradisi megibung tersebut memiliki korelasi yang sangat erat dan juga sangat terasa nuansanya pada saat pelaksanaan megibung.

\section{Pelestarian Tradisi Megibung di Desa Seraya Tengah Kecamatan Karangasem Kabupaten Karangasem}

Tradisi Megibung merupakan kegiatan yang dimiliki oleh masyarakat Karangasem yang daerahnya terletak di ujung timur Pulau Dewata. Tanpa disadari Megibung menjadi suatu maskot atau ciri khas Kabupaten Karangasem yang ibu kotanya Amlapura. Tradisi Megibung sudah ada sejak jaman dahulu kala yang keberadaannya hingga saat ini masih dapat di jumpai bahkan sudah menjadi sebuah tradisi bagi masyarakat Karangasem itu sendiri di dalam melakukan suatu kegiatan baik dalam upacara Keagamaan, Adat maupun kegiatan sehari-hari masyarakat apabila sedang bercengkrama maupun berkumpul dengan sanak saudara.

Sampai saat ini tradisi megibung masih tetap berlangsung dan tetap dipertahankan dari generasi ke generasi. Walaupun dalam perjalanannya tradisi megibung ini mengalami perubahan-perubahan, dikarenakan adanya pengaruh globalisasi. Perubahan-perubahan seperti halnya peralatan yang digunakan pada masa lalu dan masa kini mengalami perubahan yang sangat pesat. Meskipun di beberapa desa di luar Desa Seraya Tengah tradisi megibung sudah mulai terkikis karena adanya pola makan yang lebih modern seperti makan prasmanan yang sedang trend di masyarakat saat ini. Makan dengan prasmanan dianggap lebih modern dan lebih tinggi status sosialnya. Masyarakat yang mengadakan acara yadnya, yang menghidangkan makan pada para tamunya dianggap kuno dan ketinggalan jaman, serta memiliki status sosial yang rendah. Sebaliknya masyarakat yang mengadakan acara yadnya yang menyuguhkan makan dengan cara prasmanan dianggap sebagai keluarga pejabat yang modern serta memiliki status sosial yang tinggi.

Anggapan-anggapan seperti itu tentu saja akan mengancam eksistensi tradisi megibung. Karena, akan dapat menyebabkan tradisi ini ditinggalkan masyarakat. Akan tetapi hal tersebut tidak terjadi dalam masyarakat Desa Seraya Tengah, hal tersebut terbukti sampai saat ini tradisi megibung masih tetap dilaksanakan oleh masyarakat Desa Seraya Tengah. Setiap dalam upacra keagamaan seperti upacara dewa yadnya, pitra yadnya, maupun manusia 
yadnya. Tuan rumah yang mengadakan upacra yadnya umumnya akan menghidangkan makan kepada para tamunya dengan cara megibung. Kecuali untuk masyarakat yang memiliki undangan tamu dari luar Karangasem yang tidak terbiasa makan dengan cara megibung, tuan rumah biasanya akan menyediakan prasmanan.

Secara umum, berdasarkan hasil penelitian ini, bahwa tradisi megibung di Desa Seraya Tengah yang masih tetap dilakukan. Mulai dari lingkup keluarga, kelompok seka, banjar adat, dadia, sampai dengan lingkup Desa pakraman. Melihat hal tersebut dapat disimpulkan bahwa tradisi megibung di Desa Seraya Tengah masih dilestarikan sampai saat ini. Walaupun jaman sudah semakin maju dengan adanya pengaruh dari perkembangan globalisasi, seperti makan dengan cara prasmanan, akan tetapi masyarakat Desa Seraya Tengah tetap mempertahankan tradisi megibung, hal tersebut dapat dilihat dari pelaksanaan magibung yang masih tetap dilaksanakan oleh masyarakat Desa Seraya Tengah mulai skup yang paling kecil yaitu keluarga sampai skup yang paling besar yaitu Desa Pakraman.

Berdasarkan hasil pengamatan penulis, diketahui bahwa dalam megibung melalui beberapa proses yaitu proses persiapan, proses pengolahan, dan proses megibung. Adapun upaya pemerintah desa mempertahankan tradisi megibung dari segi sebagai penentu kebijakan kepada kelihan banjar dinas agar menyampaikan kepada masyarakat bahwa megibung adalah tradisi yang harus dijaga dan dilestarikan untuk mempererat persatuan dan kesatuan lingkungan.

Usaha-usaha yang sudah dilakukan oleh pemerintah dan masyarakat Desa Seraya Tengah untuk melestarikan tradisi megibung diantaranya dengan terus mengadakan megibung disetiap kegiatan di masyarakat, sehingga secara tidak langsung megibung sudah menjadi kebiasaan di masyarakat.

Adapun upaya-upaya pemerintah desa dalam mempertahankan tradisi megibung kepada masyarakat untuk menghimbau agar tetap melaksanakan tradisi megibung. Tidak ada kendala dan tidak ada ancaman dalam pelestarian tradisi megibung.

\section{SIMPULAN DAN SARAN}

Tradisi megibung ini diawali ketika terjadi perang antar kerajaan nusantara, yang bertujuan untuk memperluas daerah kekuasaan. Dalam pertempuran tersebut, banyak menguras energi dari para prajurit Kerajaan Karangasem, sehingga para prajurit tersebut menjadi sangat lapar. Pada saat para sipir (petugas membawa makanan kerajaan) yang akan diberikan kepada para prajurit, peralatan yang akan digunakan untuk membagi makanan tidak mencukupi karena banyaknya prajurit yang akan diberi makan. Sedangkan saat itu, belum ada perabotan yang lengkap seperti sekarang yang ada hanya wadah dari kau kulak (tempurung kelapa). Dalam situasi seperti itu, akhirnya I Gusti Anglurah Ketut Karangasem selaku senapati memerintahkan kepada petugas yang membawa makanan untuk membatalkan membagi-bagikan makanan dan memerintahkan kepada prajuritnya untuk memakan makanan tersebut secara bersama-sama menggunakan peralatan perang yang ada berupa tameng (ende) yang dibawa oleh prajurit tersebut sebagai alat berperang. Sejak saat itulah dikenal istilah megibung. magibung menjadi tradisi bagi masyarakat Karangasem, Khususunya masyarakat Desa Seraya Tengah yang masih tetap dipertahankan sampai saat ini. Makna yang terkandung di dalam tradisi megibung adalah menjaga persatuan dan kesatuan. 
Nilai-nilai sosial budaya yang mendasari tradisi megibung di Desa Seraya Tengah Kecamatan Karangasem Kabupaten Karangasem yaitu: 1. nilai kekeluargaanmegibung dapat memupuk dan mempererat rasa persaudaraan dan kekeluargaan. 2. nilai kebersamaan Semua orang akan bergotong royong menyelesaikan pekerjaan yang ada tanpa membedakan status sosial yang ada 3. nilai religius Nilai religius yang terkandung dalam tradisi megibunug yaitu bakti ring sang hyang widhi, Mengandung arti bahwa manusia harus berbakti kepada Tuhan Yang Maha Esa/ Ida Sanghyang Widhi Wasa.

Tradisi megibung biasanya dilaksanakan oleh masyarakat Desa Seraya Tengah dalam setiap acara-acara keagamaan, seperti upacara dewa yadnya, manusia yadnya, dan pitra yadnya. Hampir di setiap pelaksanaan upacara keagamaan tersebut pasti akan dilaksanakan megibung, pelaksanaan upacara tidak akan terasa lengkap apabila tidak di barengi dengan megibung. Tradisi megibung di Desa Seraya Tengah masih dilestarikan sampai saat ini. Walaupun jaman sudah semakin maju dengan adanya pengaruh dari perkembangan globalisasi, seperti makan dengan cara prasmanan, akan tetapi masyarakat Desa Seraya Tengah tetap mempertahankan tradisi megibung. Seiring berjalannya waktu maka akan semakin banyak terjadi suatu perubahan, hal ini akan menjadi sebuah tantangan bagi masyarakat Desa Seraya Tengah untuk tetap menjaga tradisi megibung. Tradisi megibung harus dapat dipertahankan pelaksanaanya sehingga tidak menjadi tradisi yang punah.

\section{DAFTAR PUSTAKA}

Basudewa, Dewa Gede Yadhu (mahasiswa program studi arkeologi) BASMERAH:NANGLUK MERANA CEREMONY TRADITION AT TAMAN POHMANIS VILLAGE, DENPASAR. Jurnal penelitian sejarah dan nilai tradisional vol. 22, no. 1, maret 2015.

Bungin, Burhan. 2001. Metodologi Penelitian Kualitatif. Jakarta: PT Raja Grafindo Persada

Cholid Naburko. Abu Achmadi. 2005. Metodologi Penelitian. Jakarta: Bumi Aksara

Djunaidi Ghony dan Fauzan Almanshur. 2012. Metodologi Penelitian Kualitatif. Jogjakarta: AR-RUZZ MEDIA.

Permana, I Nyoman Bayu. 2014. Megibung Dalam Pemertahanan Tradisi Adat Dan Budaya Di Desa Adat Kemoning Kecamatan Klungkung Kabupaten Klungkung Dilihat Dari Dimensi Nilai Moral Pancasila. Skripsi. Universitas Pendidikan Ganesha.

Sudiantika, I Putu Arta. 2014. Eksistensi Awig-awig Subak Dalam Pelestarian Subak Di Desa Lelateng, Kecamatan Negara, Kabupaten Jembrana. Skrpsi. Universitas Pendidikan Ganesha.

Sudaryathi, Ni Kadek Ayu Desi. 2014. Pelaksanaan Upacara Ngusaba Goreng di Desa Pakraman Karangsari, Kecamatan Selat, Kabupaten Karangasem(Kajian Tentang Pewarisan Nilai-Nilai Yang Terkandung Dalam Upacara Ngusaba Goreng. Skripsi. Universitas Pendidikan Ganesha.

Setyadi, I Made Wahyu. 2014. Peranan Tradisi Ngedeblag Sebagai Wujud Pewarisan Adat Terhadap Kehidupan Sosial dan Budaya di Desa 
Pakraman Kemenuh, Kecamatan Sukawati, Kabupaten Gianyar. Skripsi. Universitas Pendidikan Ganesha.

Sudjarwo.2001. Metodologi Penelitian Sosial. Bandar lampung: Mandar Maju.

Netra. 1974. Metodologi Penelitian. Singaraja: Biro Penelitian dan Penerbitan FKIP Unud. 